\title{
Perancangan Sistem Integrasi Administrasi Dan Keuangan Dalam Pelayanan Tera dan Tera Ulang Timbangan
}

\author{
(Studi Kasus di UPT Metrologi Legal Kota Bandung)
}

\author{
Riska Noviastuty \\ Program Studi Teknik Industri \\ Universitas Langlangbuana \\ riska_noviastuty@yahoo.com \\ Leni Herdiani \\ Program Studi Teknik Industri \\ Universitas Langlangbuana \\ leni.herdiani@gmail.com
}

\author{
Arief Ginanjar \\ Program Studi Teknik Informatika \\ Universitas Langlangbuana \\ arief.ginanjar@unla.ac.id
}

\begin{abstract}
Abstrak - Dengan adanya pelimpahan kewenangan urusan kemetrologian dari pemerintah provinsi ke pemerintah kabupaten/kota berdasarkan UU No. 23 Tahun 2014, maka banyak bidang atau unit pelaksana kemetrologian yang berdiri di daerah. Tidak terdapat perubahan terhadap pelaksanaan teknis kegiatan tera/tera ulang alat ukur, takar, timbang, dan perlengkapannya (UTTP), namun setiap pemerintah daerah memiliki regulasi administrasi dan pelaporan keuangan tersendiri. Oleh karena itu sistem administrasi dan pelaporan keuangan lingkup kemetrologian juga perlu untuk dilakukan penyesuaian. Sejak tahun 2017, UPT Metrologi Legal Kota Bandung telah mengadopsi dan melakukan inovasi pelayanan administrasi tera/tera ulang dari pemerintah provinsi. Beberapa prosedur pengadministrasian dokumen yang masih manual telah dikomputerisasi dengan menggunakan Ms.Excel, namun hal tersebut masih dirasa belum cukup. Pesatnya perkembangan teknologi informasi menuntut sistem pelayanan administrasi dan keuangan untuk lebih cepat pula, sehingga perlu adanya sebuah sistem informasi untuk mendukungnya. Sistem integrasi administrasi dan keuangan berbasis data internet dirancang untuk membantu meningkatkan kecepatan dan kualitas pelayanan adminitrasi dan keuangan tera/tera ulang timbangan di kantor UPT Metrologi Legal Kota Bandung. Dari hasil analisis dapat diketahui bahwa dengan adanya sistem informasi ini dapat mempermudah rekapitulasi administrasi dan sinkronasi pelaporan keuangan. Sehingga dengan adanya sistem informasi ini dapat disusun rekomendasi SOP kegiatan pelayanan administrasi dan keuangan tera/tera ulang yang lebih efektif dan efisien.
\end{abstract}

Kata kunci: UTTP, tera, tera ulang, sistem informasi, database

\section{PENDAHULUAN}

Sejak terbitnya Undang-Undang Nomor 23 Tahun 2014 Tentang Pemerintahan Daerah, pelayanan tera dan tera ulang alat ukur, takar, timbang, dan perlengkapannya (UTTP) yang sebelumnya berada pada kewenangan daerah tingkat I atau provinsi berpindah menjadi kewenangan kota/ kabupaten. Sehingga masing-masing kota/ kabupaten dituntut untuk memiliki unit pelaksana kemetrologian tersendiri. Pelayanan tera dan tera ulang UTTP yang bersifat teknis ini tentunya tidak terlepaskan dari lingkup administrasi yaitu pendataan dan pelaporan keuangan yang dilaksanankan pada unit pelaksana kemetrologian dimasing-masing daerah.

Pada bulan Januari tahun 2017 UPT Metrologi Legal Kota Bandung telah dibentuk untuk melaksanakan pelayanan tera dan tera ulang UTTP di Kota Bandung. Secara umum tidak

terdapat perbedaan signifikan dalam pelaksanaan kegiatan dan prosedur teknis tera dan tera ulang UTTP. Namun dalam bidang administrasinya sebagian besar masih mengadopsi sistem yang ada dipemerintahan provinsi, dimana dalam pendokumentasian datanya masih dilakukan secara manual. Data-data UTTP tersebut dicatat secara manual dalam buku-buku register besar.

Pada tahun pertama pelaksanaan administrasi di UPT Metrologi Legal Kota Bandung telah dilakukan komputerisasi kegiatan pengadministrasian UTTP dengan menggunakan Ms.Excell, namun hal ini masih dianggap kurang maksimal. Ms.Excell sangat membantu dalam rekapitulasi dan perhitungan, namun dianggap masih kurang efektif karena tidak representative untuk digunakan sebagai sistem integrasi administrasi dan keuangan yang ideal. Semakin banyak ruang lingkup tera dan tera UTTP yang dimiliki oleh sebuah unit pelaksana teknis kemetrologian, maka akan semakin rumit pula pendokumentasian data UTTP. Selain itu, dokumentasi 
UTTP ini harus tersinkronisasi dengan sistem pelaporan keuangan yang ada pada pemerintah daerah masingmasing.

Berdasarkan Pasal 3 ayat 1 Peraturan Wali Kota Bandung Nomor 382 Tahun 2017, pelayanan tera dan tera ulang UTTP dilakukan di dua tempat yaitu di kantor UPT Metrologi Legal dan di luar kantor. Dalam makalah ini sistem informasi dirancang untuk pelayanan tera/tera ulang UTTP di kantor, khusus untuk UTTP jenis timbangan. Dengan adanya sistem informasi tersebut diharapkan dapat mempercepat pelayanan, sistem administrasi, dan keuangan sehingga dapat diberikan rekomendasi terhadap penyusunan Standar Operasional Pelayanan (SOP) administrasi tera/tera ulang UTTP di kantor.

Berdasarkan paparan latar belakang yang telah dijelaskan sebelumnya, dapat diidentifikasi permasalahan yang terjadi yaitu lamanya proses pengadministrasian data UTTP dan rekapitulasi laporan dikarenakan belum adanya sistem informasi yang terintegrasi untuk memudahkan dalam rekapitulasi data dan pelaporan keuangan lingkup tera dan tera ulang UTTP. Selain itu kondisi juga diperparah karena belum adanya Standar Operasional Pelayanan (SOP) administrasi tera/tera ulang UTTP di kantor UPT Metrologi Legal Kota Bandung. Sedangkan tujuan penelitian ini adalah membuat perancangan sistem informasi berbasis data internet untuk keperluan dokumentasi UTTP sehingga dapat mempermudah rekapitulasi administratif dan sinkronasi pelaporan keuangan.

Manfaat yang diharapkan dalam penelitian ini adalah memberikan rekomendasi sistem informasi yang sesuai dengan karakteristik dokumentasi UTTP yang efektif dan efisien sehingga dimasa mendatang dapat digunakan sebagai bahan penyusunan SOP yang ideal.

Batasan-batasan yang digunakan dalam penelitian ini dapat dijelaskan sebagai berikut :

1. Sistem informasi yang akan digunakan adalah internet Database yang dirancang khusus untuk pelayanan tera/tera ulang timbangan yang dilakukan di kantor UPT Metrologi Legal Kota Bandung.

2. Hasil implementasi sistem informasi yang dirancang akan digunakan sebagai bahan untuk rekomendasi penyusunan SOP pelayanan administrasi dan keuangan tera/tera ulang di kantor UPT Metrologi Legal Kota Bandung.

3. Penyusunan rekomendasi SOP pelayanan administrasi dan keuangan tera/tera ulang berdasarkan PERMENPAN Nomor PER/21/M.PAN/11/2008 Tentang Pedoman Penyusunan Standar Operasional Prosedur (SOP) Administrasi Pemerintahan.

\section{METODE}

\subsection{Analisis Proses Bisnis Sistem Yang Sudah Ada (Eksisting)}

Untuk dapat mengetahui proses bisnis yang digunakan dalam sebuah kegiatan dalam suatu instansi makan dapat dibuat BPMN (Bussiness Process Model and Notation). Business Process Model and Notation (BPMN) merupakan standar pendiskripsian proses bisnis yang digambarkan dengan menggunakan notasi. BPMN digunakan untuk menjembatani perbedaan persepsi antara Business Analyst, System Analyst dan programmer dalam proses desain program dengan eksekusi pembuatan aplikasi.[1][7][8] Dengan adanya BPMN ini maka akan dapat dilakukan analisis terhadap proses-proses yang dianggap kurang maksimal untuk senlanjutnya dari hasil analisis ini digunakan sebagai dasar untuk perancangan sistem informasi yang akan dibuat (lihat Lampiran 1).

\subsection{Metode Perancangan Perangkat Lunak}

Dalam perancangan perangkat lunak, diperlukan metode perancangan untuk mengetahui secara lebih mendetail dari tujuan perancangan itu sendiri. Didalam model perancangan, perlu dilakukan identifikasi secara lebih mendalam mengenai sistem yang diinginkan, desain perangkat lunak yang diinginkan, dan tentunya feedback user atau customer. Dalam sejarah perkembangan rekayasa perangkat lunak sendiri telah terjadi beberapa evolusi model perancangan yang meliputi : code-and-fix model, the stage-wise model, the waterfall model, prototype model, dan sebagainya. Dalam penelitian ini digunakan prototype model dalam proses perancangan sistem. Prototype model adalah salah satu pendekatan dalam rekayasa perangkat lunak yang secara langsung mendemonstrasikan bagaimana sebuah perangkat lunak atau komponen-komponen perangkat lunak akan bekerja dalam lingkungannya sebelum tahapan konstruksi aktual dilakukan.[2]

Dalam penerapan metode prototype model, yang selanjutnya akan disebut prototyping, didefinisikan sebagai proses pengembangan replikasi produk atau sistem yang sedang dirancang. Prototyping menawarkan replika dari produk yang akan diproduksi yang selanjutnya akan diuji di lingkungan nyata atau pasar melalui penilaian para user atau customer. Dari hasil pengujian lingkungan atau pasar akan diperoleh feedback dari user yang selanjutnya akan digunakan untuk perbaikan prototype. Prototype ini kemudian kembali diuji di lingkungan pengguna untuk mendapatkan hasil yang diinginkan, proses ini akan terus diulang apabila belum didapatkan hasil yang diinginkan. Pada Gambar.1 berikut dapat diketahui proses dari penyempurnaan perancangan sebuah prototype. 


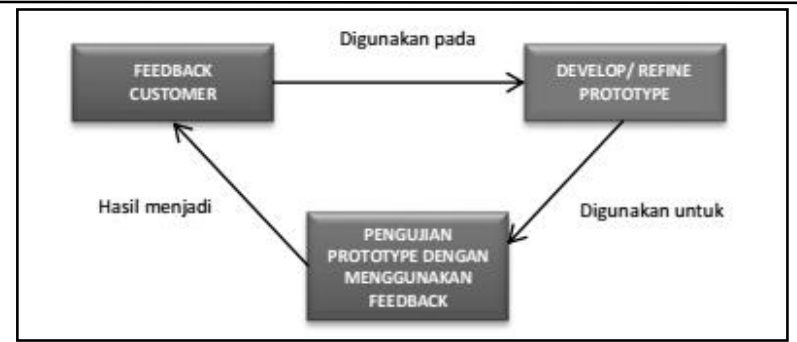

Gambar.1 Proses Penyempurnaan Prototype

Tahap-tahap dalam prototyping boleh dikatakan merupakan tahap-tahap yang dipercepat. Strategi utama dalam prototyping adalah mengerjakan yang mudah terlebih dahulu dan sampaikan hasil kepada pengguna sesegera mungkin. Terdapat enam tahapan metode pototyping yang secara ringkas dapat dijelaskan sebagai berikut

1. Identifikasi kandidat prototyping. Kandidat dalam kasus ini meliputi user interface (menu, dialog, input dan output), file-file transaksi utama, dan fungsifungsi pemrosesan sederhana.

2. Rancang bangun prototype dengan bantuan software seperti word processor, spreadsheet, database, pengolah grafik, dan software CASE (ComputerAided System Engineering).

3. Uji prototype untuk memastikan prototype dapat dengan mudah dijalankan untuk tujuan demonstrasi.

4. Siapkan prototype USD (User's System Diagram) untuk mengidentifikasi bagian-bagian dari perangkat lunak yang di-prototype-kan.

5. Evaluasi dengan pengguna untuk mengevaluasi prototype dan melakukan perubahan jika diperlukan.

6. Transformasikan prototype menjadi perangkat lunak yang beroperasi penuh dengan melakukan penghilangan kode-kode yang tidak dibutuhkan, penambahan program-program yang memang dibutuhkan dan perbaikan dan pengujian perangkat lunak secara berulang.[3]

Enam tahapan prototyping yang telah dijelaskan dapat dilihat pada Gambar.2.

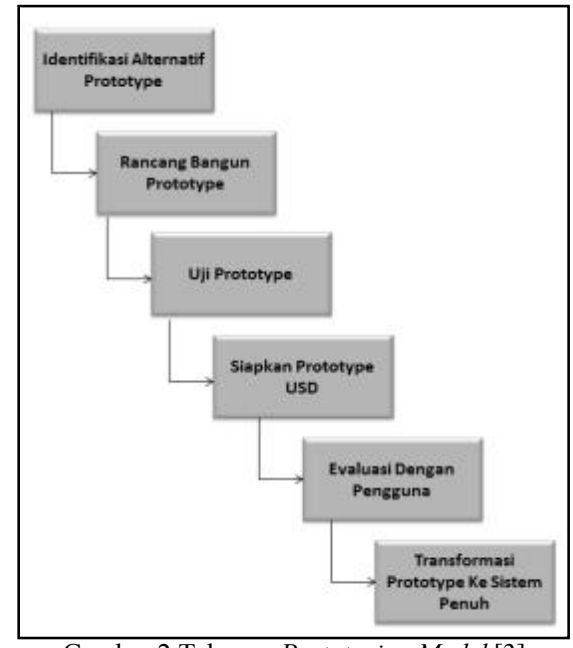

Gambar.2 Tahapan Prototyping Model.[3]

\section{HASIL PERANCANGAN, IMPLEMENTASI, DAN PENGUJIAN.}

\subsection{UML (Unified Modeling Laguage)}

Perancangan sistem informasi dalam penelitian ini menggunakan metodologi UML (Unified Modeling Laguage) yang merupakan metodologi pemodelan berorientasi objek yang digunakan untuk melakukan perancangan sebuah sistem. UML sendiri terdiri dari himpunan struktur dan teknik untuk pemodelan desain program yang berorientasi objek. UML berfungsi sebagai bahasa untuk menentukan, memvisualisasikan, membangun, mendokumentasikan dalam suatu sistem informasi. Dengan adanya UML maka akan mempermudah komunikasi secara tidak langsung antar developer untuk melakukan pengembangan program. Berikut bagian-bagian UML sistem informasi yang dirancang.

\section{Usecase diagram \\ 2. Activity diagram \\ 3. Sequence diagram \\ 4. Class diagram}

\subsection{Perancangan Database}

Berikut ini adalah bagian-bagian database yang dirancang dalam sistem informasi.

\section{Tabel database}

\section{Normalisasi database}

\section{ERD dan kardinalitas}

\subsection{Hasil Perancangan Interface}

Dari seluruh perancangan yang telah dilakukan akan membentuk sistem informasi tera dan tera ulang timbangan secara utuh yang struktur menunya dapat dilihat pada Gambar.3 berikut ini.

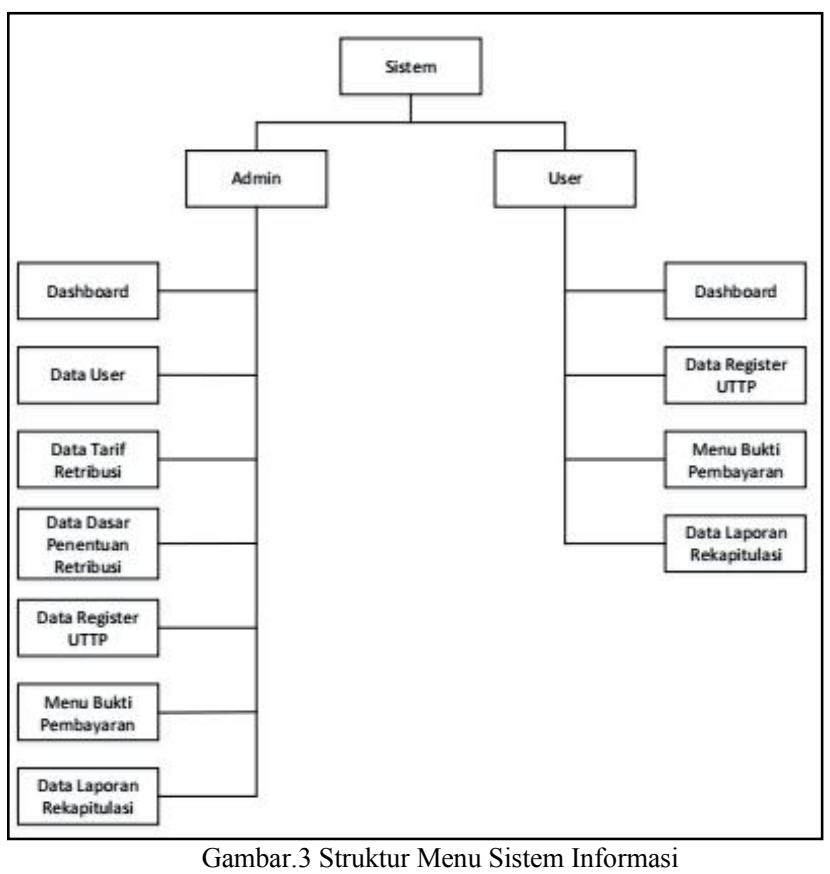




\subsection{Metode Pengujian Perangkat Lunak Menggunakan Metode Black Box Testing.}

Black Box Testing atau pengujian black box merupakan salah satu metode yang digunakan untuk melakukan pengujian pada sistem perangkat lunak yang telah dibuat dengan didasarkan pada spesifikasi perangkat lunak itu sendiri.Metode ini digunakan untuk mengetahui apakah perangkat lunak berfungsi dengan benar. Dalam pengujian black box, penguji tidak harus menguji secara detail kedalam pemrograman sistem namun lebih menekankan pada operasi perangkat lunak dimana input yang diujikan apakah diproses oleh perangkat lunak dan diperoleh output sesuai dengan yang diharapkan.[4][5]

Teknik pengujian black box berfokus pada domain informasi dari perangkat lunak, dengan malakukan test case dengan mempartisi domain input dari suatu program dengan cara memberikan cakupan pengujian yang mendalam. Dengan adanya metode ini maka segala kesalahan ataupun kegagalan akan lebih terseleksi. Pengujian black box digunakan untuk menemukan hal-hal berikut :

1. Fungsi yang tidak benar atau tidak ada.

2. Kesalahan antarmuka (interface errors).

3. Kesalahan pada struktur data dan akses basis data.

4. Kesalahan performansi (performance errors).

5. Kesalahan inisialisasi dan terminasi.

Pengujian black box didesain untuk mengetahui kinerja sistem perangkat lunak yang meliputi :

1.Kevalidan fungsi-fungsi yang dimiliki oleh perangkat lunak.

2.Kesesuaian input yang dapat diolah oleh perangkat lunak.

3.Sensitivitas perangkat lunak terhadap input-input yang diberikan dalam pengujian.

4. Isolasi data.

5.Rata-rata dan jumlah data yang mampu ditangani oleh sistem.

6.Efek apa yang dapat membuat kombinasi data ditangani spesifik pada operasi sistem. [6]

\subsection{Analisis Pengaruh Sistem Informasi Pada Pelayanan Administrasi}

Sistem integrasi tera dan tera ulang timbangan dirancang berdasarkan hasil analisis BPMN eksisting yang telah dilakukan sebelumnya. Maka apabila BPMN eksisting dan BPMN setelah adanya sistem informasi disandingkan akan terlihat perbedaan, yaitu adanya pemotongan proses dan efektifitas serta efisiensi kerja (lihat Lampiran 2).

Atara BPMN eksisting dengan BPMN setelah adanya sistem informasi yaitu sebagai berikut :

1.Pada BPMN eksisting kwitansi masih ditulis tangan secara manual,sedangkan pada BPMN setelah SI (Sistem Informasi) kwitansi dapat dicetak secara otomatis melalui sistem.

2.Pada BPMN eksisting petugas harus melakukan dua kali input data yaitu input data register dan melakukan input data kembali saat melakukan rekapitulasi dalam proses pembuatan laporan. Sedangkan pada BPMN setelah SI petugas cukup hanya melakukan satu kali input data register, selanjutnya untuk rekapitulasi laporan petugas lebih dipermudah dengan adanya fiture rekapitulasi laporan secara otomatis yang ada dalam sistem informasi.
Dari perbandingan kedua BPMN yang telah dilakukan, maka dapat diketahui bahwa keberadaan sistem integrasi tera dan tera ulang timbangan ini dapat mempermudah kinerja petugas administrasi tera dan tera ulang. Sehingga dapat dikatakan BPMN setelah adanya SI dapat digunakan sebagai dasar penyusunan rekomendasi SOP pelayanan administrasi keuangan tera/tera ulang (lihat Lampiran 3).

\section{KESIMPULAN}

Dari hasil perancangan, pengujian, dan evaluasi terhadap keberadaan sistem integrasi tera dan tera ulang timbangan ini dapat disimpulkan sebagai berikut.

1. Sistem integrasi tera dan tera ulang timbangan berbasis data internet telah dirancang sesuai dengan karakeristik dokumentasi UTTP yang efektif dan efisien, sehingga dapat digunakan untuk keperluan dokumentasi dapat mempermudah rekapitulasi administrasi dan sinkronisasi pelaporan keuangan.

2. Dengan adanya sistem informasi ini maka dapat disusun rekomendasi SOP kegiatan pelayanan administrasi dan keuangan tera/tera ulang yang lebih efektif dan efisien.

\section{DAFTAR PUSTAKA}

[1] Brainmatics., Bussiness Process Model and Notation (BPMN). http://brainmatics.com/business-process-modeland-notation-bpmn/. Diakses 21 November 2018.

[2] Gobioff, Howard; Gibson,Garth; Tygar,Doug, Security for Network Attached Storage Devices,USA:1997

[3] JR.,Harris; D.W.,Parker; Evaluation of Rapid Prototyping Methodology in a Human Interface, 1987

[4] Jogiyanto. Pengenalan Sistem Informasi.Tata,Sutabri. 2004.

[5] Kadir, Abdul. Pengenalan Sistem Informasi. Yogyakarta : Andi, 2003

[6] Tata,Sutabri, Analisa Sistem Informasi. Yogyakarta: Andi, 2004

[7] Dwipriyoko, E. Literature Review on New Generation Cooperative Enterprise Architecture, Jurnal TIARSIE, Vol.14(1), 51-56, 2017

[8] Dwipriyoko, E. Perancangan Arsitektur Aplikasi Open Source untuk Koperasi Generasi Baru, Studi Kasus Koperasi Terbaik Malaysia, SNIA 2017 UNJANI, Computer Crime and Digital Evidence, 3, 145-150, 2017

[9] Ginanjar, A., \& Supendi, Y., Kansei Engineering Implementation in Designing a News Portal for Education and Child Health Information Mobile Website Interface, Jurnal TIARSIE, 14(1), 1-12., 2017

[10] Herdiani, L., \& Syafarudin, R., Line Balancing Demi Tercapainya Efisiensi Kerja Optimal Pada Stasiun Kerja. Jurnal Tiarsie, 15(2), 49-54., 2018 
Lampiran 1. BPMN Sistem Eksisting

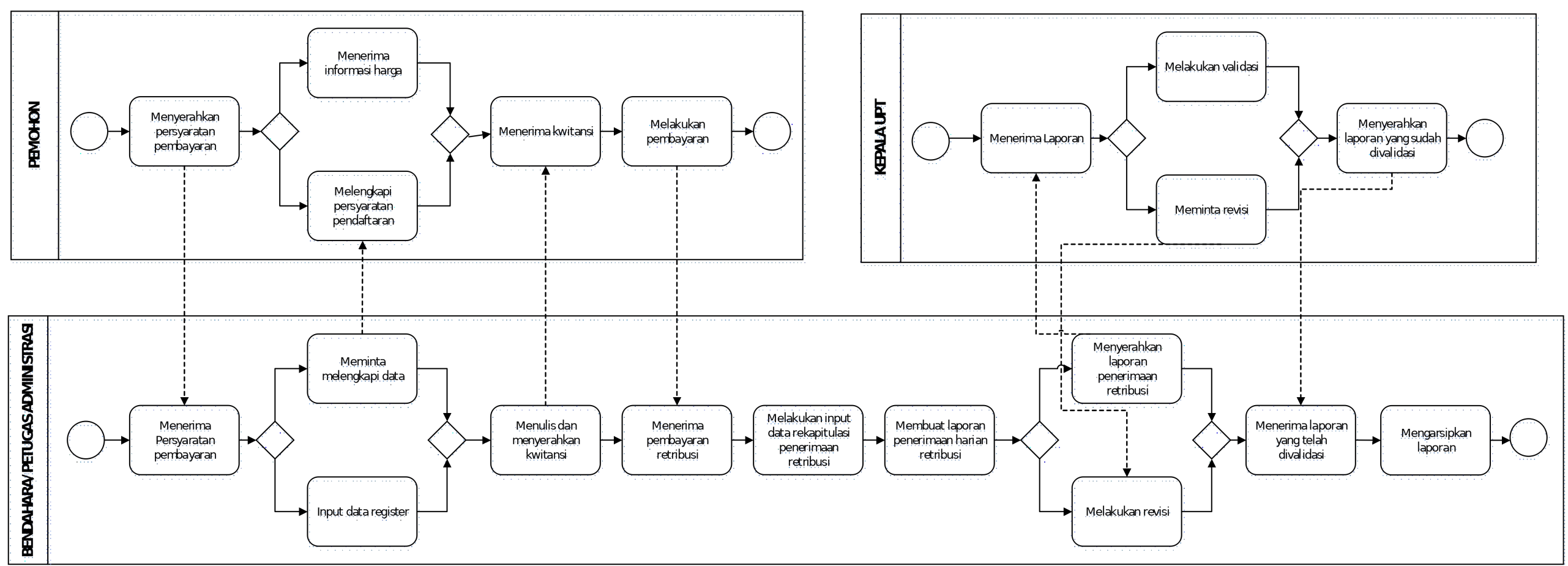


Lampiran 2. Perbandingan BPMN Eksisting dengan PBMN setelah adanya SI

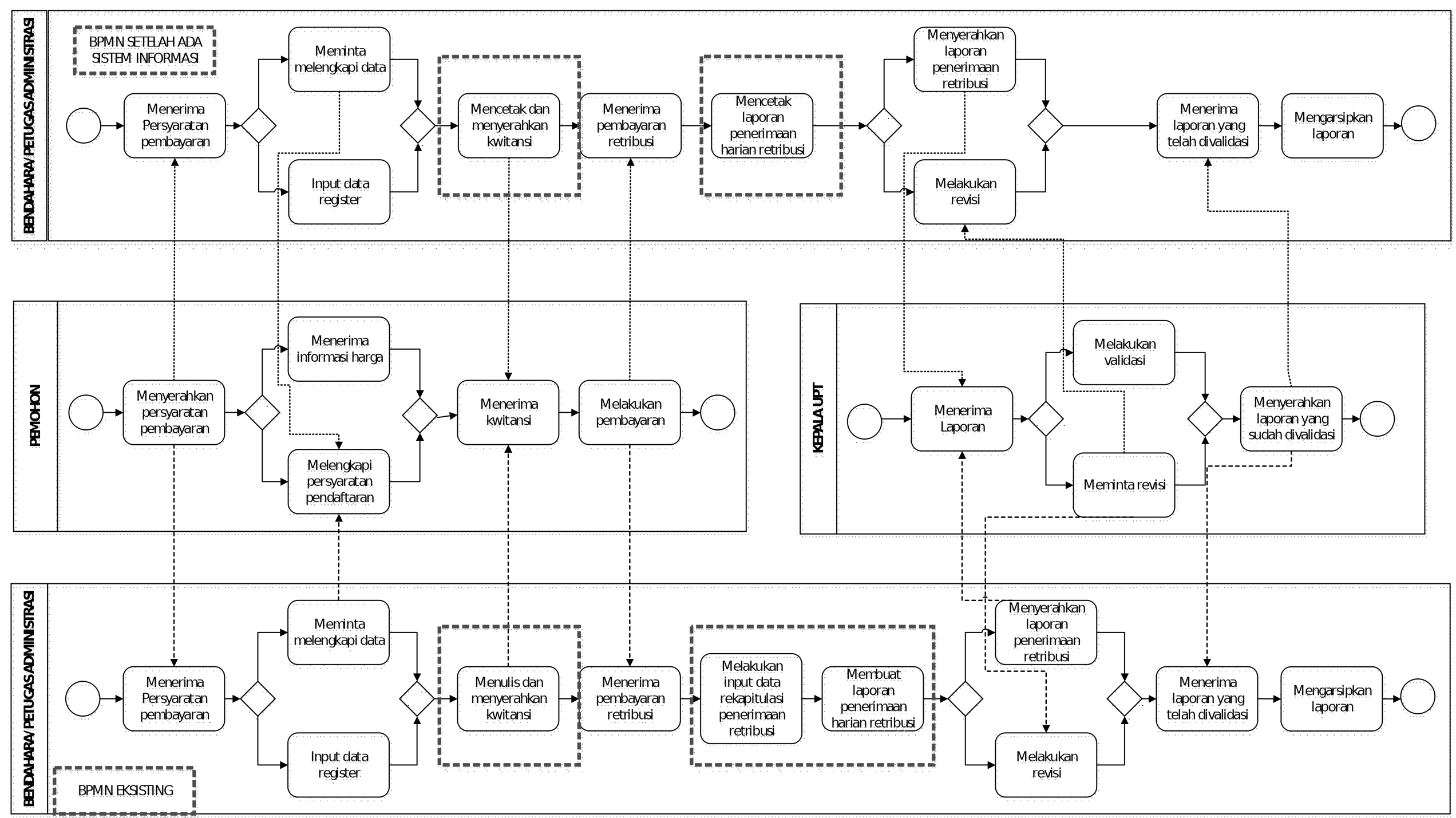


Lampiran 3 SOP Pelayanan Administrasi dan Keuangan Tera/Tera Ulang di Lingkungan Dinas Perdagangan dan Perindustrian Kota Bandung

\begin{tabular}{|c|c|c|c|c|c|c|c|c|}
\hline \multirow[b]{2}{*}{ No. } & \multirow[b]{2}{*}{ Aktivitas } & \multicolumn{3}{|c|}{ PELAKSANA KEGIATAN } & \multicolumn{3}{|c|}{ MUTU BAKU } & \multirow[t]{2}{*}{ KET } \\
\hline & & Pemohon & $\begin{array}{c}\text { Bendahara/ } \\
\text { Petugas }\end{array}$ & $\begin{array}{c}\text { Kepala } \\
\text { UPT }\end{array}$ & Kelengkapan & Waktu & Output & \\
\hline 1 & $\begin{array}{l}\text { Pemohon melengkapi dan menyerahkan persyaratan } \\
\text { pembayaran. }\end{array}$ & & & & $\begin{array}{l}\text { Formulir } \\
\text { pendaftaran, berita } \\
\text { acara hasil } \\
\text { pengujian tera/tera } \\
\text { ulang }\end{array}$ & $\begin{array}{c}3 \\
\text { menit }\end{array}$ & $\begin{array}{l}\text { Formulir dan } \\
\text { kelengkapan persyaratan } \\
\text { pembayaran }\end{array}$ & \\
\hline 2 & $\begin{array}{l}\text { Bendahara/petugas administrasi } \text { menerima dan } \\
\text { memeriksa kelengkapan persyaratan pembayaran. }\end{array}$ & Tidak & & & $\begin{array}{l}\text { Formulir } \\
\text { pendaftaran, berita } \\
\text { acara hasil } \\
\text { pengujian tera/tera } \\
\text { ulang }\end{array}$ & $\begin{array}{c}2 \\
\text { menit }\end{array}$ & $\begin{array}{l}\text { Formulir pendaftaran, } \\
\text { berita acara hasil } \\
\text { pengujian tera/tera } \\
\text { ulang yang telah } \\
\text { diperiksa }\end{array}$ & \\
\hline 3 & $\begin{array}{l}\text { Bendahara/petugas administrasi melakukan input data } \\
\text { register. }\end{array}$ & & & & $\begin{array}{l}\text { Berita acara hasil } \\
\text { pengujian tera/tera } \\
\text { ulang }\end{array}$ & $\begin{array}{c}2 \\
\text { menit }\end{array}$ & $\begin{array}{l}\text { Nilai retribusi/ hasil } \\
\text { perhitungan register }\end{array}$ & \\
\hline 4 & $\begin{array}{l}\text { Bendahara/petugas administrasi mencetak } \\
\text { menyerahkan kwitansi, serta mengarsipkan } \\
\text { kwitansi, dan kelengkapan pembayaran. }\end{array}$ & & & & $\begin{array}{l}\text { Hasil perhitungan } \\
\text { register dan nomor } \\
\text { referensi register }\end{array}$ & $\begin{array}{c}2 \\
\text { menit }\end{array}$ & $\begin{array}{l}\text { Kwitansi, Arsip copy } \\
\text { kwitansi dan dokumen } \\
\text { kelengkapan } \\
\text { pembayaran. }\end{array}$ & \\
\hline
\end{tabular}




\begin{tabular}{|c|c|c|c|c|c|c|c|c|}
\hline \multirow[b]{2}{*}{ No. } & \multirow[b]{2}{*}{ Aktivitas } & \multicolumn{3}{|c|}{ PELAKSANA KEGIATAN } & \multicolumn{3}{|c|}{ MUTU BAKU } & \multirow[t]{2}{*}{ KET } \\
\hline & & Pemohon & $\begin{array}{c}\text { Bendahara/ } \\
\text { Petugas }\end{array}$ & $\begin{array}{c}\text { Kepala } \\
\text { UPT }\end{array}$ & Kelengkapan & Waktu & Output & \\
\hline 5 & $\begin{array}{l}\text { Pemohon menerima kwitansi dan melakukan } \\
\text { pembayaran retribusi. }\end{array}$ & & & & Kwitaisi & $\begin{array}{c}1 \\
\text { menit }\end{array}$ & Uang retribusi & \\
\hline 6 & 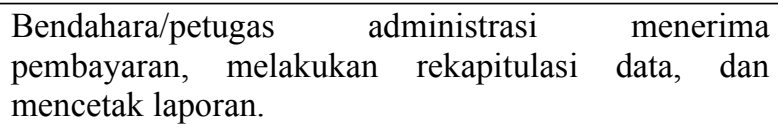 & & $\checkmark$ & & Data register & $\begin{array}{c}5 \\
\text { menit }\end{array}$ & $\begin{array}{l}\text { Laporan penerimaan } \\
\text { retribusi tera/tera ulang }\end{array}$ & \\
\hline 7 & $\begin{array}{l}\text { Bendahara/petugas administrasi menyerahkan laporan } \\
\text { penerimaan retribusi kepada kepala UPT. }\end{array}$ & & & & $\begin{array}{l}\text { Laporan } \\
\text { penerimaan } \\
\text { retribusi tera/tera } \\
\text { ulang }\end{array}$ & $\begin{array}{c}2 \\
\text { menit }\end{array}$ & $\begin{array}{l}\text { Laporan penerimaan } \\
\text { retribusi tera/tera ulang }\end{array}$ & \\
\hline 8 & $\begin{array}{l}\text { Kepala UPT menerima dan memeriksa laporan } \\
\text { penerimaan retribusi. }\end{array}$ & & Tidal & & $\begin{array}{l}\text { Laporan } \\
\text { penerimaan } \\
\text { retribusi tera/tera } \\
\text { ulang }\end{array}$ & $\begin{array}{c}20 \\
\text { menit }\end{array}$ & $\begin{array}{l}\text { Laporan penerimaan } \\
\text { retribusi tera/tera ulang } \\
\text { yang telah diperiksa }\end{array}$ & \\
\hline 9 & $\begin{array}{l}\text { Kepala UPT memvalidasi laporan penerimaan } \\
\text { retribusi dan menyerahkan berkas laporan yang telah } \\
\text { divalidasi kepada bendahara. }\end{array}$ & & & $\downarrow$ & $\begin{array}{l}\text { Laporan penerimaan } \\
\text { retribusi tera/tera } \\
\text { ulang yang telah } \\
\text { diperiksa }\end{array}$ & $\begin{array}{c}3 \\
\text { menit }\end{array}$ & $\begin{array}{l}\text { Laporan penerimaan } \\
\text { retribusi tera/tera ulang } \\
\text { yang telah divalidasi }\end{array}$ & \\
\hline 10 & $\begin{array}{l}\text { Bendahara menerima berkas laporan yang telah } \\
\text { divalidasi dan mengarsipkannya. }\end{array}$ & & & & $\begin{array}{l}\text { Laporan } \\
\text { penerimaan } \\
\text { retribusi tera/tera } \\
\text { ulang yang telah } \\
\text { divalidasi }\end{array}$ & $\begin{array}{c}10 \\
\text { menit }\end{array}$ & $\begin{array}{l}\text { Arsip laporan } \\
\text { penerimaan retribusi } \\
\text { tera/tera ulang }\end{array}$ & \\
\hline
\end{tabular}

